\title{
Duas questões permanentes em um século de políticas de saúde no Brasil republicano
}

\author{
Two permanent issues in a century \\ of health policies in Republican Brazil
}

\footnotetext{
${ }^{1}$ Instituto de Medicina Social da Universidade

do Estado do

Rio de Janeiro

Rua São Francisco Xavie

$524 / 7$ o andar, bloco E,

Maracanã, 20550-013

Rio de Janeiro RJ

madelluz@uol.com.br
}

\begin{abstract}
This article discusses the dilemma centralization versus decentralization in health policies of the republican Brazilian State during the twentieth century. It develops the central hypothesis that the dichotomy centralization/ decentralization of functions, services and activities in Brazilian public policies, mainly in the health policies, expresses the concentration/deconcentration dichotomy of social power in civil society. The centralization/decentralization dichotomy as it appears in health policies since the foundation of Brazilian republic, illustrates the authoritarian character of this republic, as a consequence of the concentration of the social power in the hands of a small elite. Analysis of health policies in different conjunctures seems to demonstrate that decentralization tends to be defined by the state and other political actors in a geopolitical sense, rather than in a political sense. The article demonstrates also that during the 90s there has been a real process of decentralization, but still with a very little distribution of power.
\end{abstract}

Key words Health Policies; Democracy; Centralization/Decentralization; Concentration/ Deconcentration
Resumo Este artigo discute o tema da centralização versus descentralização das politicas de saúde do Estado brasileiro no século XX. Desenvolve como hipótese central a idéia de que a questão centralização/descentralização de serviços e funções nas políticas públicas, incluindo a de saúde, exprime no Estado a concentração do poder social na sociedade brasileira. A dicotomia centralização/descentralização seria a transposição institucional da concentração/desconcentração do poder social e sua tradução na ordem política. A centralização no Estado materializa a estrutura de concentração do poder institucional, que as politicas públicas exprimem, durante quase todo o século XX, apesar das interferências de vários movimentos da sociedade civil. Analisando as políticas de saúde em diversas conjunturas, e destacando a progressiva diversificação de atores políticos que nelas intervêm, o artigo conclui pela existência de um processo de efetiva descentralização nas políticas na década de 1990, embora sem uma verdadeira desconcentração do poder político.

Palavras-chave Políticas de Saúde; Democracia; Centralização/Descentralização; Concentração/Desconcentração 


\section{Introdução}

No momento em que o século XX se encerra como o mais vertiginoso e denso em mudanças tecnológicas, políticas e relacionais dos séculos conhecidos, com profundas repercussões sobre a vida social, o Brasil assinala pouco mais de cem anos de regime republicano. Nesse período as transformações históricas, no que concerne às relações sociais, sobretudo quando se consideram as políticas públicas, não registram nem de longe o mesmo ritmo do século.

Acredito que este é um bom momento para passar em revista alguns traços permanentes, isto é, que se observam repetitivos, com características estruturais, nas políticas públicas republicanas brasileiras, sobretudo naquelas que concernem à vida e à saúde coletivas. Talvez seja também importante revisar aspectos mais sublinhados na literatura produzida sobre essas políticas. O que significa, para a autora, nela situar-se durante a redação do trabalho, fazendo de sua produção um balanço retrospectivo.

É possível que estes se tornem os objetivos principais e o conteúdo central do trabalho em início. Se ele conseguir superar com espírito de síntese e clareza o que lhe falta em dados empíricos para uma verdadeira revisão de fatos e de literatura, terá alcançado uma finalidade importante, que é a de chamar a atenção para alguns traços fundamentais recorrentes das políticas de saúde e sua significação na vida cotidiana e institucional em nosso país.

Quero sublinhar desde logo que este trabalho, diferentemente de outros que produzi na área de Políticas de Saúde (Luz, 1979; 1982; 1991), ${ }^{1}$ geralmente voltados para as relações entre instituições e Estado, não é resultante de uma pesquisa empírica sociohistórica. Resulta de reflexões sobre a leitura de autores que venho consultando para participar em debates e dar aulas sobre Instituições e Políticas de Saúde na pós-graduação em saúde coletiva na UERJ, e sobre as dissertações e teses que venho orientando nos últimos cinco anos. ${ }^{2}$ Assim igualmente decorre da análise de teses que venho tendo a oportunidade de argüir como membro das bancas de exame versando sobre instituições e políticas de saúde e nutrição. Acredito que essas três fontes de dados constituem um acervo de teorias, idéias e fatos que me permitem levantar hipóteses sobre questões permanentes na política de saúde brasileira. Permitem-me também avançar afirmações e articu- lações teóricas sobre o Estado em suas relações com as instituições e a sociedade civil brasileira numa perspectiva sociopolítica, embora sem a pretensão de substituir as bases de dados que uma pesquisa empírica direcionada ao tema poderia obter.

\section{Duas dicotomias históricas permanentes nas políticas públicas e de saúde: centralização/descentralização, concentração/desconcentração}

Tomarei como tema central de discussão duas dicotomias, isto é, duas questões que se apresentam recorrentes e polarizadas em um século de políticas públicas no Brasil, utilizando-me do caso da saúde como referência e ilustração. Assinalo, entretanto, que essas dicotomias têm viabilizado alianças históricas com pesos e sentidos políticos diferentes em conjunturas distintas.

A primeira delas é centralização/descentralização. Essa dicotomia aparece recorrentemente desde a fundação da República, em relação a que esfera do governo brasileiro (federal, regional, estadual, local) caberia o desempenho de determinadas funções. Ou ainda que serviços compete ao Estado, no nível do poder executivo central, prestar à população? ${ }^{3}$ À República Federativa, materialização do poder central, atribui-se o desempenho das funções que dizem respeito à nação como totalidade, à conservação de sua unidade e/ou integridade. O difícil tem sido decidir, em cada conjuntura política e circunstância histórica, o que diz respeito a essa totalidade. No caso das políticas de saúde pública, por exemplo, o combate às epidemias e endemias e seu controle parecem ter sido sempre um tema tipicamente referido ao poder nacional central. Entretanto, desde que as condições de financiamento e de estruturação logística das atividades envolvidas nesse combate deixam de ter caráter emergencial, e a necessidade de investimento sistemático do poder público se impõe como função institucional, superando o modelo campanhista (Luz, 1979, 1982, 1991), ${ }^{4}$ esvai-se a certeza de que o controle desta ou daquela epidemia deveria ser atribuição do poder central. Um caso jocoso, embora grave do ponto de vista das conseqüências para a saúde pública, ilustrativo desta tendência, é o da controvérsia recorrente no século XX, vista ora como banal ora como politicamente insolúvel, do combate aos mosquitos de diversas "febres tropicais" (malária, febre amarela, den- 
gue): o mosquito é federal, estadual ou municipal?

A segunda questão, aparentemente idêntica ou decorrente da primeira, mas remetendo a estruturas de poder social mais básicas, referese à dicotomia concentração/desconcentração nas políticas públicas. Tal questão diz respeito àquilo que se delega como poder decisório nessas políticas, e a quem se delega. Em outras palavras: quem decide sobre metas e, sobretudo, sobre as formas de financiamento que fazem descer tais metas da retórica discursiva (leis, normas, programas) para sua efetivação prática e seu desenvolvimento, com todas as conseqüências daí recorrentes? Embora essas questões não sejam separáveis, podem e devem ser distinguidas e discutidas. Na história das políticas de saúde em nosso país, freqüentemente, sobretudo na segunda metade do século, verificou-se uma sutil divisão entre a prestação ("administração") de serviços e sua "gestão" (controle de recursos), tendente a manter o caráter centralizador das políticas públicas brasileiras através do controle do gerenciamento dos recursos no nível federal. Tal concentração só encontrou um limite no final do século, na década de 1990, com a entrada em execução da política municipalista do Sistema Único de Saúde (SUS), através da regulamentação das Normas Operacionais Básicas (NOB). Apesar de algumas contradições e confrontos provocados pela política descentralizadora do SUS com a política neoliberal, esta última voltada para o desmonte do sistema público de serviços, é inegável o processo de descentralização gestionária dos serviços de saúde verificado durante a última década do século. Comentarei esse processo no fim deste trabalho.

Uma primeira hipótese que esboço a este respeito é que historicamente se identificou e confundiu, tanto no plano fatual como no das análises das políticas públicas do país, descentralização com desconcentração. ${ }^{5}$ No plano dos fatos históricos essa identificação/confusão teve o sentido de minimizar possíveis perdas de poder político do nível central, definindo em termos geopolíticos, se podemos dizer assim, uma divisão do poder que envolveu sempre muito mais do que simples delegação de funções institucionais em termos territoriais. No plano das análises, essa identificação ratifica a compreensão territorialista da divisão do poder político presente no estado nacional, deixando de elucidar a questão da natureza pré-democrática do poder central entre nós (Luz, 1992). ${ }^{6}$ Esse se apresenta historicamente como portador de um universalismo social abstrato, contraposto aos poderes regionais/locais e às demandas organizadas da sociedade civil. Os últimos seriam vistos a priori como particularistas, isto é, defensores de uma acumulação particular (regional/local/corporativa) de poder, opondo-se assim ao poder politicamente "universalista" do Estado Nacional. A oposição política central/ regional nasceu desse pressuposto. Talvez seja importante debruçar-nos sobre as origens históricas dessa pressuposição republicana ainda não superada nas políticas públicas, ao menos nas de saúde e previdência, indagando-nos sobre suas bases sociais.

É, evidente que a República brasileira não se originou de uma grande transformação social, ou seja da substituição de um regime de produção e de relações sociais por outro, mais avançado. Isso sucedeu nas grandes nações européias, onde o capitalismo em substituição ao feudalismo fez surgir não apenas a república moderna como regime político. Mas também a democracia moderna como regime social (Marshall, 1964) foi paulatinamente implantada na Europa e nos Estados Unidos da América durante os séculos XIX e XX.7

A República brasileira é um filho temporão do século passado, uma medida política tardiamente tomada num dos últimos reinos escravistas do continente.

Os atores políticos que tomaram a medida de proclamar a República, dentre os quais destacam-se os militares positivistas, não representavam, como salientam historiadores políticos (Carvalho, 1990), movimentos de massa ou partidos populares. ${ }^{8}$ Estavam mais ligados a clubes ou centros de discussão elitistas, ou participavam de partidos ligados a interesses regionais de produção mais "avançada" (em direção ao capitalismo, é claro), em geral, de produtos agropecuários de exportação. Esses constituíam a fonte das receitas e da dívida (crescente) do estado brasileiro: o café, o leite, o algodão, o fumo, o açúcar e, mais tarde, a borracha etc.

O Segundo Império foi o domínio conciliador desses interesses regionalistas até enquanto pôde. Isto é, até quando a existência de um regime de produção escravista não atrapalhou ostensivamente os negócios das nações republicanas industrialistas, sobretudo da hegemônica Inglaterra. Tráfico de escravos, mão-deobra não-assalariada, ou sub-assalariada, muito restrito consumo de bens manufaturados, um regime de produção com mínima circula- 
ção monetária e menor circulação de idéias em uma população iletrada e carente, tudo isso representou obstáculo considerável para a expansão de uma economia de mercado com vocação mundial como é a economia capitalista industrial. O bloqueio monetário, ou pelas armas, quando necessário, às atividades ligadas ao outro regime de produção, e ao regime político que o representou em uma sociedade com grande potencial de inclusão na economia de mercado, tornou-se inevitável e compreensível deste ponto de vista. Este quadro, mais externo que interno, foi determinante para o advento da República em nosso país, trazendo uma série de conseqüências de natureza política e social, entre as quais destacam-se as dicotomias políticas sublinhadas acima, como a do centralismo versus regionalismo ou melhor dizendo, da centralização versus descentralização.

A hipótese aqui, certamente não original, mas importante para situar a questão central do artigo, é que a República assim fundada não é politicamente instalada em toda a sua plenitude nem mesmo no plano formal, jurídico. Impõe-se de cima para baixo sobre forças e instituições sociais vigentes que rejeitam na prática os princípios universalistas da República democrática com suas conseqüências: a efetiva separação dos poderes executivo, legislativo e judiciário; o controle mútuo desses poderes no intuito de preservar a Nação do arbítrio dos socialmente poderosos; a horizontalização das relações no plano jurídico através do reconhecimento formal do primeiro princípio da cidadania - todos os homens nascem livres e iguaise o exercício do poder do Estado como expressão de uma vontade geral através do voto (reconhecimento jurídico-político da cidadania).

Esses princípios, consagrados pela revolução francesa há mais de dois séculos na Carta dos Direitos do Homem, e ratificados, um século e meio depois, na Declaração Universal dos Direitos Humanos, não se implantaram plenamente em nosso país nesses cento e dez anos de República. As resistências sociais ao regime republicano estariam, segundo grande parte dos estudos socioeconômicos e políticos, enraizadas nos poderes sociais regionalistas mais atrasados, em oposição aos poderes regionalistas avançados. A perspectiva histórico-estrutural de origem marxista apontou muito esses aspectos em suas análises econômicas, históricas e sociológicas dos anos 70 (Albuquerque, 1981; Carone, 1977; Fernandes, 1975; Ianni, 1971a, 1971b, 1973, 1974, 1975; Martins, 1975; Kowa- rick, 1971; Moura, 1978; Oliveira, 1977; Pinheiro, 1975; Singer, 1976; Vianna, 1976; Weffort, 1973, 1978), ${ }^{9}$ acentuando a posição dos atores na estrutura das forças produtivas e das relações sociais de produção, como determinantes das posturas políticas mais centralistas ou mais regionalistas.

Sem desconsiderar o que há de consistente e ainda atual nessas análises, pode-se observar que o centralismo político presente nas políticas públicas brasileiras pode muito bem coadunar-se com o regionalismo corporativista dos interesses sociais - freqüentemente locais na República brasileira. Que se tome como exemplo a política do café com leite na primeira metade do século findo. Desejo neste momento opor à interpretação tradicional de centralismo versus regionalismo outra interpretação: a de que o centralismo político é coerente com o regionalismo (particularista) social da República brasileira. Desta forma, uma república centralizadora do poder político como a nossa é coerente com uma sociedade particularista (concentradora de poder) do ponto de vista social. A unidade política necessária ao funcionamento das instituições republicanas nessa estrutura é obtida à custa de um poder centralizador e concentrador de decisões. O poder unitário tende a ser um poder autoritário, acima da sociedade, e não fruto do consenso na diversidade da sociedade civil (poder democrático). A sociedade política não representa a sociedade civil: paira acima dela, como diria Gramsci, não a integrando senão de maneira instável e coercitiva. As políticas públicas, sobretudo as sociais, são um exemplo da permanência secular destas características: unitárias, verticais e instáveis.

A primeira conseqüência deste processo, em termos político-sociais, é que não chega a se constituir, neste contexto, uma República de cidadãos associados ou organizados por interesses comuns, ou mesmo nitidamente separados por interesses econômicos, políticos ou culturais divergentes, típica das nações democráticas modernas (Vianna, 1998). Tendeu a formar-se, com as transformações históricas que beneficiaram a tendência individualista do capitalismo durante o século XX, uma república de indivíduos que buscam, na maioria das vezes de forma hobbesiana, sua própria sobrevivência. Isso se dá de forma distanciada da solidariedade social que constitui a matéria-prima da sociedade civil democrática e a identidade básica do cidadão. 
Uma segunda conseqüência é a confusão política perversa - no sentido em que tende a haver simbiose - entre o político e o civil. Tal confusão se traduz quotidianamente na sociedade em um desconhecimento prático, pelos cidadãos, de quais são os limites entre o individual e o coletivo, ou do que constitui a distinção básica entre público (coisa pública) e privado (propriedade particular). Este desconhecimento coletivo, embora atinja a todos, beneficia sistematicamente os mais bem-situados na escala social. Os detentores de maior faixa de poder, tendem a impor, através da política, por meio dos poderes constituídos, seus interesses particularistas (muitas vezes corporativos) à grande massa social. Fazem triunfar normas e decisões políticas que lhes são favoráveis em detrimento das necessidades e interesses da maioria. No caso das políticas públicas e sociais, este tem sido um fato notável nos últimos trinta e cinco anos.

Uma terceira conseqüência, ainda mais séria no plano político, reflexo da confusão apontada acima, é que esse tipo de ordenação se transmite às instituições civis ligadas ao poder público. ${ }^{10}$ Estas, ao invés de representarem normas ou regras universais - sistemas de meios com vistas à obtenção de fins sociais, destinadas ao interesse geral e a serem cumpridas igualmente por todos, como propõe idealmente a república moderna em seus princípios, ${ }^{11}$ constituem-se em núcleos burocráticos concentradores de poder, voltados para si mesmos. Isto é, investem na sua própria reprodução, aceitando que perante as normas, em princípio, todos são iguais, mas há alguns mais iguais que outros (Luz, 1992).

O tipo de relação social que tende a se estabelecer entre as instituições com esta característica estrutural (a de se tomarem como fins em si mesmas) e a sociedade é de mando e não de serviço, assumindo um papel de controle sobre os cidadãos. A burocracia gerada e treinada nesse processo vê-se como gendarme da sociedade política (Estado) e não como servidora da sociedade civil, embora remunerada com os recursos do contribuinte. A vontade política desse tipo de instituição é, como afirmei há pouco em nota, imperial, portanto pré-republicana e - acrescento - pré-democrática, tendendo a ver os cidadãos como vassalos do poder público (Faoro, 1958). Estes, por sua vez, como o lado civil da moeda, tendem a ver as instituições não como fruto da sociedade, portanto como manifestação histórica de suas lutas ou necessidades sociais, mas como entidades particulares, manifestação da grande entidade soberana que é o Governo (Estado). As relações dos simples cidadãos com essas entidades, através de atitudes tendem a ser de manipulação ou subserviência no sentido de obterem, dos burocratas, certos favores de tipo clientelista, geralmente para serviços a que têm direito constitucional (Luz, 1992).

Sublinhei os termos relativos à tendência para ressalvar que no desenvolvimento histórico do processo político brasileiro nem sempre essas tendências se confirmaram. Por um lado, organizaram-se movimentos sociais pela cidadania que em diversas conjunturas do século, lideradas por trabalhadores organizados (Primeira República) ou não (segunda metade do século XX, sobretudo a partir dos anos setenta), que agitaram a república. Eles apontam para uma sociedade civil que busca fazer-se presente na cena histórica no sentido de exigir do estado, geralmente quase arrancar, direitos políticos, econômicos e sociais de cidadania. Esses movimentos mostram a existência, na sociedade brasileira, de uma face política bem menos passiva, embora pouco ouvida, que a de uma república de indivíduos. ${ }^{12}$

Por outro lado, embora não se possa afirmar que a burocracia brasileira seja a realização do modelo weberiano da racionalidade burocrática, seria injusto não tributar a certos servidores públicos estatais, principalmente em saúde e educação, os históricos e às vezes heróicos (considerados os insuficientes recursos físicos, humanos e financeiros) esforços feitos para preservar e assegurar tais serviços à população. Contribuem para isso não apenas profissionais ligados às atividades institucionais "fins" (ensino, atenção à saúde), mas também os ligados às atividades burocráticas. Além disto, pode-se observar, quando se estudam essas instituições, a permanência de uma identidade corporativa de servidor público que o Estado brasileiro até o presente momento não conseguiu demolir por completo nem mesmo com as sucessivas políticas de "desmonte" da prestação de serviços pelo estado, dos governos da última década do século. Em algumas conjunturas, como a da década de 1970, no auge do período autoritário militar, e nos anos 90, com a violência das políticas sociais neoliberais, os servidores civis dessa área, burocratas ou não, adotaram e adotam até o presente, atitudes de resistência à privatização das políticas públicas, no sentido de preservar direitos historicamente conquistados. $\mathrm{O}$ 
que não tem impedido, certamente, que fossem - e continuem sendo - derrotados.

Essas ressalvas visam a salientar que, embora as tendências estruturais da república brasileira não tenham se atenuado com um século de existência, apresentando de forma acentuada seu caráter de concentração de poder em todos os níveis ao longo do século findo, tem havido e continua a haver resistência a essas tendências, tanto no interior das instituições quanto na sociedade civil. Em outras palavras, a centralização que se observa nas políticas públicas até o fim do século XX, e a dificuldade da delegação de funções e distribuição de recursos são simplesmente a manifestação política, no Estado, da concentração de poder social característico da sociedade brasileira. ${ }^{13} \mathrm{O}$ Estado, coerente com sua composição social, não chega a delegar poder nem no plano das instituições (delegação de funções, diversificação de instâncias de decisões) nem no plano da sociedade civil (consulta, diálogo ou negociação com atores que a representam). A conclusão das reflexões desenvolvidas até o momento é de que a dicotomia centralização versus descentralização (política) exprime no plano das políticas públicas a dicotomia concentração versus desconcentração (social) persistente na sociedade brasileira, mas com ela não se identifica.

\section{Centralização versus descentralização nas políticas de saúde do Brasil}

Meu interesse central neste trabalho é examinar a presença e a permanência dessas aparentes dicotomias nas políticas e instituições de saúde no Brasil republicano, e suas conseqüências no nível social. A hipótese interpretativa básica, enunciada acima, é que a "dicotomia" histórica centralização/descentralização é a tradução institucional da questão da concentração do poder social manifestada na estrutura política brasileira. Examinarei brevemente como essa questão se traduziu nas políticas e instituições de saúde.

A República Velha foi, desde sua primeira Constituição de 1891, autoritária, como acentuei em trabalhos anteriores (Luz, 1979, 1982, 1991), e como tentei demonstrar no início deste presente trabalho, pelas razões analisadas. Não por acaso seu primeiro momento (18891993) é conhecido como República da Espada. A política de saúde do início do século XX, encarnada na figura carismática de Oswaldo Cruz, foi sanitarista e seu modelo básico de intervenção social, campanhista. ${ }^{14}$ Isso significa que seu modelo institucional foi unitário, centralizado, vertical e concentrado em termos de poder político. O que não quer dizer por outro lado, que o sanitarista dispusesse de todo o poder. Oswaldo Cruz queixava-se com certa freqüência de que seus projetos sanitaristas eram geralmente podados pelo poder legislativo só lhe restando verbas para atividades emergenciais que não resolviam as questões básicas de saúde, sobretudo aquelas concernentes às epidemias e endemias (Luz, 1982).

De qualquer modo o modelo campanhista é um modelo de intervenção baseado na força da autoridade e isto, no caso da intervenção médica, significa autoridade da competência. $\mathrm{O}$ que exclui a consulta ou diálogo com aqueles julgados incompetentes ou, o que é mais comum, ignorantes, como é o caso da sociedade civil. (Luz, 1982, Costa, 1985). ${ }^{15}$ Desta forma, o modelo básico de criação da ordem sanitária brasileira no início do século XX é autoritário: unitário, vertical, centralista, concentrador de poder, característico da jovem república em constituição.

Devemos nos interrogar, entretanto, se essas características, mais que da república brasileira, não são típicas do estado nacional do fim do século XIX e início do século XX, profundamente marcados pela ideologia do progresso ligado à autoridade da ciência e da tecnologia. ${ }^{16}$ Terá o barão de Haussmann consultado ou ouvido a sociedade civil francesa quando tomou a decisão de refazer Paris, destruindo as antigas vielas históricas da cidade, geralmente transformadas em cortiços, para erguer os bulevares que fazem ainda hoje, o encanto da mais bela cidade, do mundo? Teriam sido os parisienses consultados sobre as intenções do governo francês de construir, nas entranhas da cidade um subterrâneo destinado aos transportes públicos? Não creio. As relações estado/sociedade nas repúblicas, nesse momento histórico não eram as de uma democracia participativa, características mais presentes no capitalismo do fim do século XX. São antes relações centralistas e verticalistas as que dominavam. As autoridades consideravam que sabiam o que faziam, pois estavam trabalhando pelo progresso da nação. A República brasileira, como partenaire recente da nova ordem internacional, não fugiu a este modelo; tendeu, ao contrário, a acentuá-lo. ${ }^{17}$

Oswaldo Cruz, ex-aluno do Instituto Pasteur, foi um seguidor convicto desse modelo 
(Luz, 1982) e tentou implantá-lo no Brasil com grande vigor e dinamismo. Costuma ser lembrado e louvado pelo sucesso de suas campanhas no combate às epidemias e pelas controvérsias que essas causaram na sociedade civil brasileira. Creio, porém que lhe deve ser tributada acima de tudo, e a seus discípulos do Instituto de Pesquisas que criou, dentre os quais destaca-se Carlos Chagas, a construção de um sólido aparato sanitarista no país, durante a República Velha. A eficácia desse aparato, considerando-se suas finalidades, é inegável na primeira metade do século. O que é equivalente a dizer que efetivamente existiu uma política de saúde sanitarista no Brasil até pelo menos o início dos anos 30 .

Nos anos trinta e quarenta do século XX, correspondente à Segunda República, primeiro República tenentista, depois (a partir de 1937) ditadura do Estado Novo, exercida por Getúlio Vargas, houve uma mudança significativa nas políticas sociais, sobretudo na área de saúde. Praticamente aí nasceu a previdência social como função de Estado, incluindo-se em diversos Institutos de Aposentadoria e Pensões então criados, ainda que de forma incipiente, a atenção médica individualizada (Luz, 1979, 1991; Vianna 1998). ${ }^{18}$ Os Institutos de Aposentadoria e Pensão nasceram com um modelo que inovou politicamente, pois estabeleceram como norma institucional a participação da sociedade civil, por meio da representação patronal e sindical na sua gestão. É verdade que em face da concentração de poderes nas mãos do governo, personificado na figura de Getúlio, essa participação passou a ser uma participação condicionada. O aparelho de segurança do estado, se encarregava de fazer a triagem e a seleção da representação civil nos institutos, podendo admitir, manter ou demitir de acordo com os interesses políticos e ideológicos do Estado. Os candidatos a representantes de cada campo da produção, patrões e empregados eram julgados de acordo com os interesses políticos e ideológicos do governo. O clientelismo tornou-se inevitável nesse período, e a simbiose político/civil da sociedade brasileira teve nele seu momento maior de enraizamento histórico (Luz, 1991; 1992).

Por outro lado, as instituições e a legislação criadas na época estavam voltadas para a previdência e a saúde de categorias específicas de trabalhadores, inseridos geralmente em ramos estratégicos da economia. Tinham um caráter corporativo inegável, não assegurando, a todos, os direitos sociais de cidadania ao estilo do wellfare state europeu (Santos, 1979; Vianna, 1998). Além disso, eram organizados como instituições federais de gestão centralizada, embora com agências ou escritórios regionais, seguindo neste ponto o mesmo estilo centralista e verticalizado das instituições de saúde pública originárias da Primeira República. A centralização institucional continuou, assim como a concentração do poder.

Em compensação, a estrutura do poder público e de suas instituições diversificou-se e tornou-se complexa de maneira considerável neste período. O aparato estatal republicano brasileiro desenvolveu-se, na fase getulista, no sentido de assumir funções como previdência, saúde e educação de massa, que o Estado liberal da Primeira República negava-se a assumir. Constituiu-se também, uma burocracia com o espírito weberiano de funcionário público. Carreiras e concursos, inclusive no campo da saúde pública, foram instituídos através de um órgão governamental criado para este fim, um departamento de administração do serviço público, o DASP. Entretanto, esse funcionário concebido como suporte do funcionamento do Estado não desenvolveu o espírito de um servidor civil (civil servant, para empregar a forte expressão americana) mas de um servidor do governo. Estava sendo mais forjado para defender a estrutura e as prerrogativas do Estado, do que os direitos do cidadão comum. Esta base original de formação, marcou profundamente a natureza do funcionalismo republicano brasileiro.

A expansão, diversificação e consolidação do Estado traduziu então um projeto nacionalista, no sentido de consolidar a nação brasileira a partir do comando do governo, de suas organizações e de sua burocracia, vistos sob um ângulo corporativo próximo do projeto fascista. Essa característica tem sido assinalada quase unanimemente nos estudos da história política do país.

As questões que se colocam neste contexto são: como poderia haver desconcentração do poder político nas políticas públicas em tal conjuntura? Consequentemente, que descentralização se poderia esperar da política de saúde e previdência? Seguramente, nenhuma. No entanto foram criados ministérios e legislação ligados à política social e à saúde, instituição de departamentos e serviços ligados às já tradicionais campanhas sanitárias, serviços e departamentos que passaram a ter vigência efetivamente nacional. Houve tentativas de controlar 
as endemias e epidemias em todo o território do país a partir de planos e programas voltados para este fim. Além disso, serviços hospitalares municipais foram criados ou incentivados nos grandes centros urbanos, beneficiando trabalhadores sem instituto (sem carteira assinada), ou desempregados, ou "indigentes" em geral, sendo estes últimos, pessoas sem recursos para tratamento de saúde embora não necessariamente mendigos. Em outras palavras: houve, no período, diversificação e burocratização no âmbito das políticas públicas, mas não desconcentração ou descentralização de ações ou funções. ${ }^{19}$

A economia do país também se diversificou e se tornou complexa, entrando na fase urbano-industrial. A sociedade civil, consequentemente, se desenvolveu e buscou aumentar sua participação na vida nacional, no plano cultural (começou nos anos trinta a era do rádio) e educacional e crescentemente, através de organização e sindical e partidária, no plano político. Mas essa participação era vista com temor e desconfiança pelo estado autoritário do período, que instituiu depois de 37, também como função pública, a censura, a espionagem e a tortura dos cidadãos sobre os quais recaíam denúncias e desconfiança. Foram criados com esse fim, os serviços de segurança, materializados em termos institucionais, no histórico e tristemente famoso DOPS (Departamento de Ordem Pública e Social).

Em tal contexto, o controle sobre a sociedade civil foi abrangente, como se verifica nas sociedades autoritárias. $\mathrm{O}$ poder que a burocracia, como agente do Estado e fonte de insidiosa e constante corrupção, passou a dispor sobre os simples cidadãos fez que o serviço público fosse visto como algo estranho e potencialmente hostil à alteridade, à diversidade e à divergência. Esta marca estruturante nunca abandonou por completo a burocracia ou a sociedade civil brasileira, do mesmo modo que as engrenagens dos órgãos de segurança não foram totalmente desmontados.

O período de democratização pós-guerra e de crescimento econômico da década de 1950, marcado pelo fenômeno da "guerra fria", não contribuiu para a descentralização ou desconcentração do poder na sociedade brasileira. Apesar de sua constante "complexificação" no plano econômico, com o progresso industrial em plena marcha e a expansão constante do processo de urbanização, o desenvolvimento social não ocorreu. Verificou-se o fenômeno do "inchamento" das cidades, pólos de atração de mão de obra migrante, que se tornaram metrópoles típicas das sociedades do Terceiro Mundo: sem infra-estrutura adequada para atender aos novos contingentes populacionais; sem capacidade de absorção da mão-de-obra desqualificada para atividades estáveis no sistema de produção; sem instituições para abrigar e formar os grupos humanos recém-chegados do campo em busca de sobrevivência. Por acréscimo foram se avolumando e multiplicando as favelas já existentes.

A volta de Getúlio Vargas ao poder pelo voto em 1950 ("nos braços do povo", conforme expressão da época) marcou uma série de mudanças em relação às políticas públicas, inclusive as sociais. Como criara, em seu primeiro período de poder, a Consolidação das Leis do Trabalho (CLT), conjunto de direitos sociais trabalhistas até hoje não superados na República brasileira, Getúlio preocupou-se com um conjunto de reformas das políticas econômica e social. No campo do transporte, da energia, da alimentação, da educação e da saúde (entre outras), tratou de assegurar sua universalização e sua "nacionalização", ou melhor sua estatização. O projeto político de desenvolvimento econômico nacional comandado pelo estado e nele centralizado continuou, embora sem condições de pleno êxito. A penetração do capital e da orientação política estrangeira, agora comandada pelos vitoriosos Estados Unidos da América, no período pós 2a Guerra Mundial se acentuou na gestão do general Eurico Gaspar Dutra. Com ela chegou ao Brasil a guerra fria e o combate aos vermelhos.

Uma tensão progressiva se estabeleceu entre o projeto nacionalista e desenvolvimentista do segundo período Vargas e as forças ligadas ao desenvolvimento associado ao capitalismo avançado, durante a primeira metade da década de 1950, culminando com a morte trágica de Getúlio em agosto de 54. No que concerne às políticas sociais, é interessante assinalar a criação do Ministério da Saúde. Apareceu no início de sua estruturação, por parte de um setor da burocracia desse ministério, aliada a outro pequeno setor dos profissionais da previdência social, a idéia de concretizar uma efetiva descentralização dos serviços de saúde como parte de uma reforma institucional com vistas ao desenvolvimento econômico (a educação e a saúde eram vistas então como parte importante do desenvolvimento nacional, como saída para o ciclo do subdesenvolvimento). 
Além disso, começou a se desenhar a proposta de hierarquização na prestação desses serviços, com prioridade concedida ao que posteriormente se designou como atenção primária. Evidentemente essa proposta se aliava a um projeto de estatização da atenção médica oferecida à população, no sentido de assegurar que permanecesse como um serviço público. Porém, somente no início da década de 1960 essa proposta foi formulada claramente como parte do projeto das "Reformas de Base" que o herdeiro político de Getúlio Vargas, João Goulart, proporia ao Congresso e à Nação.

Em outras palavras, no período, embora continuasse a viger o modelo centralização e concentração nas políticas sociais, começava a haver, por parte dos agentes institucionais e da sociedade civil organizada (sindicatos, associações profissionais), uma proposta de descentralização e de participação civil (portanto de desconcentração) na organização das políticas de saúde. Essas propostas tenderam, tanto durante a década de 1950 quanto no início da década seguinte, a ser acolhidas pelo Estado, através de governos posteriormente considerados populistas pelos estudiosos, ${ }^{20}$ ou denominados de "república sindical ou sindicalista" por seus opositores contemporâneos. ${ }^{21}$ Do meu ponto de vista, revisando essa conjuntura com o olhar distanciado do tempo histórico, prefiro considerar que esses governos representaram simplesmente um pequeno interregno democrático na história política autoritária da secular República brasileira. $^{22}$

Interessa-me salientar aqui, entretanto, que se o processo histórico de descentralização nas políticas sociais, sobretudo em saúde, não se efetivou nesse período, pelo menos sua discussão se iniciou, bem como a reivindicação nesse sentido, por parte de setores da burocracia ligada ao Ministério da Saúde e aos órgãos da previdência social. O debate se orientava para que a descentralização dos serviços, através de sua municipalização, levasse a uma efetiva desconcentração do poder do estado, favorecendo assim a participação popular nas políticas públicas (Luz, 1979). Seguramente a participação popular reivindicada não se referia à totalidade da população, nem mesmo a seus setores organizados. Referia-se principalmente aos próprios profissionais da saúde, a entidades sindicais e partidárias e a órgãos corporativos médicos. Mas isto já significava abrir a caixa preta das políticas públicas à participação da sociedade civil. Em outras palavras, buscava desconcentração do poder de Estado.
Entretanto, minha hipótese de base é que a concentração política apenas exprime a enorme concentração socioeconômica persistente na sociedade brasileira, manifestando a resistência de poderes particularistas regionais (avessos a mudanças no sentido universalista) profundamente arraigados no solo social. Esses poderes, geralmente de base local, corporativos e conservadores, estão dominantemente representados nos três poderes do Estado em seu nível central. E tendem a inviabilizar as tentativas de descentralização/desconcentração nas políticas públicas propostas em mais de uma conjuntura no desenvolvimento secular da República. $^{23}$

Seguramente esses poderes encontram fortes aliados na burocracia estatal, considerandose o caráter tradicionalmente centralizador e autoritário da mesma, ressalvadas as importantes exceções já descritas. Desta forma, torna-se compreensível que o fechamento político da conjuntura seguinte, do período do Estado autoritário militar, encontre respaldo nas instituições públicas, apesar das resistências já mencionadas. $\mathrm{O}$ que parece problemático e necessário de ser interrogado é a pouca resistência encontrada nas instituições e na sociedade civil brasileira quando uma ordem autoritária vem se impor à ordem democrática e a vontade popular. Sobretudo nota-se a diferença se compararmos com o verdadeiro massacre que esse tipo de ordem foi obrigada a realizar para impor-se, em outros países da América do Sul, como Argentina e Chile. Minha hipótese, que vem sendo desenvolvida ao longo dessas páginas e em outros trabalhos (Luz, 1991, 1992, 1994), é que essa baixa resistência testemunha ao mesmo tempo a fragilidade de nossa sociedade civil, marcada por desigualdade social profunda (Luz, 1992), estruturada como uma república de indivíduos; e a existência de uma ordem institucional burocrática avessa à participação da sociedade civil em suas atividades e alheia ao seu serviço. Uma ordem política quase fechada em si mesma, volta-se em grande parte para sua reprodução, em que pesem mudanças verificadas nas duas últimas décadas.

O período dos vinte anos de ditadura mili$\operatorname{tar}$ (1964-1984) caracterizou-se, como era de se esperar, por uma atividade de franca centralização e concentração do poder institucional (Luz, 1979, 1991, 1994). Uma verdadeira "reorientação" em sentido contrário ao que estava em marcha no projeto das reformas de base da conjuntura anterior, que buscava a descentrali- 
zação e a desconcentração. O período que se inaugura é marcado por excluir a participação da sociedade civil das decisões e - sobretudo do controle sobre qualquer política pública. Não insistirei aqui nesse período, exaustivamente tratado pelos sociólogos e cientistas políticos, inclusive pela autora destas páginas, no que concerne às políticas e instituições de saúde. Ele pouco nos diz ${ }^{24}$ sobre a questão da descentralização e da desconcentração a não ser em termos negativos. Opto, portanto, por analisar a conjuntura seguinte, que se inicia ainda durante o período militar

O projeto de descentralização só é retomado, em termos da sociedade política, no início da década de 1980, com a crise das políticas sociais do Estado autoritário, sobretudo nas áreas de saúde e previdência social. Esses setores estavam exauridos pela corrupção engendrada pelo autoritarismo refletido nas normas de privatização de serviços e atos médicos das duas décadas anteriores.

Falo em retomada porque os atores são essencialmente os mesmos (burocracia e profissionais da área de saúde e previdência) e o projeto é basicamente o anterior - sanitarista e desenvolvimentista (Luz, 1979), embora atualizado. A novidade, em termos políticos, é que a nova "descentralização" incorporou aos poucos o projeto dos serviços locais de saúde (SILOS) elaborado pelos organismos internacionais da ordem sanitária (OMS/OPS) nos anos 70. Também a idéia de participação cresceu e se ampliou em direção à sociedade civil, aos "usuários" dos serviços, ao invés da idéia reduzida de "comunidade", tão cara aos anos 60. Programas de descentralização municipal de serviços (como o AIS - Ações Integradas de Saúde) foram estruturados na primeira metade dos anos 80 , em acordo com prefeituras simpáticas à idéia da descentralização e da priorização dos serviços básicos de saúde. Várias experiências, continuadas depois de $84 \mathrm{com}$ a política de saúde da Nova República e com a criação do SUDS (Sistema Único Descentralizado de Saúde), foram o laboratório de elaboração do projeto Sistema Único de Saúde (SUS), que chegou praticamente pronto à VIII Conferência Nacional de Saúde em Brasília, em 1986, para onde convergiram mais de três mil pessoas, fato inédito na história dessas conferências (Luz, 1994).

É necessário reassinalar que a década de 1980 foi palco de uma progressiva movimentação social em torno das políticas públicas, principalmente a de saúde, que passou a ser vista pe- la sociedade civil organizada (associações, organizações civis, sindicatos, partidos) como direito de cidadania (Luz, 1991). Houve a formação de movimentos populares em torno das questões centrais das políticas de saúde (universalização, hierarquização e acessibilidade em relação aos serviços) bem como grande participação de grupos organizados locais (comunitários) nas Conferências de Saúde (estaduais, municipais), fruto da importância que essa questão adquiriu na política da conjuntura (Mattos, 1990). ${ }^{25}$

As reivindicações dos crescentes movimentos populares ratificaram a questão da descentralização dos serviços, adicionando a participação popular no planejamento e, sobretudo, na gestão desses serviços como elemento primordial do controle da sociedade sobre essa gestão. Essa reivindicação é também inédita por parte da sociedade civil em termos de desconcentração do poder político estatal em seu favor.

É importante assinalar aqui que a intensa movimentação da sociedade civil teve um papel muito importante para a aceitação, na política oficial, das propostas da VIII Conferência Nacional de Saúde, em grande parte consubstanciadas no SUS (Luz, 1994). O Congresso Nacional tomou em consideração e aprovou em 1988 essas propostas, não apenas, porque os antigos atores de mudanças nas políticas de saúde - profissionais de saúde, burocracia do Ministério da Saúde e da Previdência - estavam presentes e atuando ativamente neste sentido, inclusive como deputados. Mas porque havia uma efetiva participação popular na busca dessas mudanças. Pela primeira vez uma política pública se oficializou no país, que buscava, ao menos no seu discurso, a descentralização e a desconcentração em proveito de instâncias intermediárias de poder institucional. O controle social do cidadão ficou garantido através de participação em Conselhos (estaduais, municipais) destinados a este fim. A saúde tornou-se a vanguarda das políticas públicas nessa questão.

Entretanto, grande parte desse instrumento de descentralização política que é o SUS ficou sem regulamentação até o fim dos anos oitenta.

Quando se iniciou a década de 1990, os ventos políticos já sopravam a favor do neoliberalismo com a eleição do governo Collor de Mello. Começava aí um processo de desmonte de políticas sociais construídas não apenas na década anterior mas em outras, recuando-se até o momento de Getúlio Vargas e sua política 
trabalhista e previdenciária dos anos 30. Este processo completa agora uma década.

É inegável a complexificação dos contrastes e problemas crônicos da sociedade brasileira em todos os níveis (econômico, social, político e cultural), nos últimos quinze anos, esse processo é resultante não apenas do estilo de crescimento econômico e desenvolvimento social do país, ${ }^{26}$ mas também do processo conhecido como "globalização". Esse processo, em grande foco de análise, tem sido definido pelos economistas e cientistas políticos como um conjunto de mutações na estrutura da produção, nas relações sociais concernentes ao trabalho, na vida política e cultural do capitalismo em plano mundial que atinge em cheio as nações, com efeitos de grande concentração de capital nas economias centrais e de concentração de renda e desagregação social nas nações situadas na periferia do sistema. No que concerne o Brasil, se os anos 80 já tinham sido considerados por grande parte dos analistas de conjuntura (economistas, sociólogos, cientistas políticos) como perdidos do ponto de vista socioeconômico, a década de 1990 foi vista por unanimidade como década perdida tanto para a questão social como para a economia. ${ }^{27}$

A endêmica concentração de riqueza, aliada ao crescente desemprego, piorou sensivelmente com a política econômica de ajuste fiscal adotada pelos governos da década, passando a economia brasileira, como várias outras do continente, a ser "monitorada" por organismos financeiros mundiais como o FMI e o Banco Mundial. Foram implantadas nas economias periféricas do sistema políticas econômicas internacionais monetaristas centradas no "setor externo", para as quais a expansão interna da produção e do emprego nas nações forçadas a adotá-las têm pouca significação frente ao controle da dívida externa, do equilíbrio fiscal, da balança de pagamentos e da "força" da moeda. O processo de implantação desse modelo em nosso país, iniciado no governo Collor, ampliou-se e consolidou-se nos dois períodos do governo Fernando Henrique Cardoso.

A conseqüência dessas políticas tem sido o empobrecimento dos povos dos países ditos de terceiro mundo ou "emergentes", que acontece numa escala e com uma rapidez jamais antes presenciada no capitalismo. ${ }^{28}$ Multidões de pobres são continuamente jogadas nas ruas desses países, pelo desemprego, pelo encarecimento da moradia, pelas doenças, pela velhice sem amparo. São populações vistas como "descartá- veis", como acentuaram estudiosos da questão da transformação do regime de trabalho e das condições sociais no capitalismo globalizado (Castel, 1995; Kurz, 1997; Tavares e Fiori, 1997, Soares, 1999), inaugurando uma nomenclatura tristemente incorporada pela midia. A perda de status e de capacidade de consumo, com inevitável declínio econômico e social das camadas médias tradicionais (pequenos comerciantes, comerciários, profissionais liberais, bancários, funcionários públicos civis e militares), é outro subproduto inegável do processo de mudança na economia em plano nacional e internacional.

Nesse contexto, os jovens dificilmente encontram lugar no núcleo dinâmico do sistema de produção, independentemente de sua qualificação (evidente que quanto menos qualificado o jovem, menor probabilidade de encontrar um emprego terá); os maduros são expulsos de seus empregos pelo encolhimento dos postos de trabalho, sobretudo na indústria; os que perdem o emprego têm grande dificuldade em voltar para o sistema; como conseqüência, a economia informal acaba por atingir praticamente $50 \%$ do volume da atividade econômica global.

Todos esses fatos, conhecidos não apenas dos estudiosos das condições de vida da sociedade brasileira, mas da opinião pública, uma vez que são continuamente divulgados pela grande imprensa, ${ }^{29}$ são mencionados aqui apenas para chamar a atenção para a importância que terão como resultado final em termos de aumento de demanda de atenção médica. Atingem duramente a população, sobretudo em termos de sofrimento mental, motivando uma verdadeira crise na estrutura de atendimento da saúde pública.

Acompanha o tipo de política econômica que provoca esses efeitos uma estratégia (também política, a meu ver) de cortes de verbas para as políticas públicas. Dentre elas estão a da previdência, da saúde, da educação e a do "setor social" em geral, incluindo-se o desfinanciamento a pesquisas científicas e tecnológicas, sobretudo na área social, meio como forma de contenção de gastos. Embora seja sabido que o corte em outras fontes de gastos, como juros, despesas com os gastos financeiros da dívida externa - e interna - e cobrança dos impostos devidos por empresas e bancos, aportaria recursos orçamentários mais volumosos e contínuos para as necessidades da sociedade brasileira de atribuição do estado. 
A proposta política do Estado com essa estratégia é encolher-se ao nível mínimo, deixando em mãos privadas, filantrópicas ou voluntárias, às quais faz apelos constantes e incisivos de participação e parceria, atividades concernentes ao setor social secularmente definidas como funções públicas essenciais. Também por isso essa forma de Estado tem sido denominado entre nós neoliberal, como alusão ao estado liberal clássico do fim do século XIX e da Primeira República, ou República Velha, no início do século XX. ${ }^{30}$

O Estado neoliberal tem governado e dominado o cenário entre nós nos últimos dez anos e todos temos ciência do que tem sido sua política de saúde: corte de verbas, desmonte do setor público e desvio de verbas destinadas à saúde para outros gastos. Não pretendo determe nestes aspectos, também ampla e quotidianamente debatidos e denunciados pelos analistas do campo e pela midia. Eles não constituem, apesar de sua enorme importância, o ponto básico deste artigo. Proponho-me aqui a analisar, ainda que brevemente, o que esta política implica em relação às questões centrais destas páginas, isto é, questão das polaridades centralização/descentralização e concentração/desconcentração.

Em aparente paradoxo, o Estado neoliberal tende a favorecer a descentralização. Digo $a p a-$ rente porque no plano financeiro os governos neoliberais tendem a centralizar os recursos da União, que passam a ser controlados pela sua equipe econômica, através da concentração dos mesmos nos ministérios ligados à economia, e a exercer sobre os outros ministérios e sobre as unidades da federação (estados e municípios) um controle férreo, estabelecendo um conjunto de regras contábeis para o repasse dos recursos provenientes dos impostos a essas unidades. No desenvolvimento desta lógica de "repasses", a partir de um certo ponto, o poder central passa a agir como um agente financeiro em relação a esses entes públicos, "emprestando-lhe" os recursos necessários para obras de investimento, custeio e folha de salários. Como conseqüência dessa lógica os estados e municípios não apenas passam a depender do poder central para desempenhar a contento suas atividades, como tendem a endividar-se para além do que permitiriam as receitas provenientes de suas unidades. ${ }^{31}$ Cria-se um círculo vicioso semelhante ao que enfrenta o próprio estado nacional face aos organismos financeiros internacionais. Desse ponto de vista, o Estado neoliberal é o mais centralista de todos os que a República brasileira pôde conhecer no século findo.

Do ponto de vista da concentração do poder, esse tipo de centralização enseja formas de manipulação e corrupção políticas também inéditas no país, pois o que mais senão isto (manipulação e corrupção) poderia ser tão bem resumido na frase tomada ao príncipe dos mendigos: "é dando que se recebe"? ${ }^{32}$ Através do controle dos recursos, o poder central negocia, desvia, cerceia ou libera as verbas em princípio destinadas a setores sociais básicos, como saúde e previdência social. $O$ poder legislativo e o executivo nos níveis estadual e municipal acabam tornando-se reféns dessa política. E o país, entre atônito e deprimido assiste ao balcão de "negociações" corporativas das verbas públicas em que se transformaram as relações entre os poderes da República.

Por outro lado, o núcleo central do Estado faz o que pode para livrar-se do ônus político, social e econômico crescente que representam saúde e previdência, transferindo para unidades periféricas do poder público as funções e sobretudo, as responsabilidades concernentes a essas funções. Esta delegação, prevista num instrumento de descentralização de política pública como é o SUS, torna-se uma forma de o Estado central desincumbir-se das funções que lhe foram constitucionalmente atribuídas. Entretanto, o "repasse" dos recursos necessários para o desempenho dessas funções não se faz no mesmo ritmo nem com a mesma presteza que lhe são repassadas as obrigações. Desta forma, se quisesse resumir numa formulação clara e simples a política de descentralização da saúde dos governos neoliberais da última década, poderia dizer que esta tem consistido em transferir ("delegar") funções para unidades, estatais territorialmente menores (estados, municípios, locais), no sentido de poder "cobrar" dessas unidades responsabilidades referentes às funções delegadas, com o menor dispêndio político e financeiro possível.

Evidentemente, esta é apenas uma das perspectivas políticas envolvidas na questão da descentralização/desconcentração da política de saúde, embora seja a que mais pese em termos de conseqüências para a sociedade civil e para a nação como um todo, considerada a importância do ator político envolvido nessa perspectiva. Mas há também as perspectivas de outros atores, já presentes nas conjunturas anteriores, como os profissionais de saúde, as buro- 
cracias da área de saúde e a sociedade civil, que merecem ser analisadas.

Além disto, novos atores que crescem na conjuntura dos anos 90 necessitam ser colocados em exame para que se tenha uma visão mais global e mais nítida da complexidade do problema. É sobre esse conjunto de atores que me proponho a fazer algumas observações nas linhas a seguir, salientando a continuidade de sua importância no debate político a partir da segunda metade dos anos oitenta (Luz, 1991, 1994).

Em primeiro lugar, cabem algumas palavras sobre os atores tradicionais da discussão sobre centralização/descentralização nas políticas de saúde. Refiro-me aos profissionais (médicos, enfermeiros, psicólogos, nutricionistas etc.) e a certos setores da burocracia da área presente nos Ministério da Saúde e Previdência Social. Creio que esses atores evoluíram de uma visão corporativa estrita (portanto particularista) dos anos 60 para uma visão mais democratizante (portanto mais universalista) nos anos 90. Passaram a ter uma interlocução muito mais madura com a sociedade civil organizada (associações, organizações, sindicatos, setores de partidos etc.) e estiveram junto com ela na exigência de sua participação no planejamento e na gestão (controle social) dos serviços de atenção primária à saúde, através de Conselhos (em níveis estadual, municipal, local) integradores de sua representação. Mais que isso: foram geralmente esses atores - o que não quer dizer sempre, pois resistências houve e ainda hoje há muitas - que propuseram e fizeram implantar tais Conselhos nas secretarias de saúde nos diversos níveis.

Profissionais e burocratas (inclusive gestores) são, portanto, uma força política que atua no interior do Estado (nas instituições estatais de saúde) ou na periferia do Estado (nas instituições corporativas de saúde) no sentido de produzir um movimento de desconcentração do poder estatal de dentro para fora, num processo de descentralização através do favorecimento da co-gestão institucional em todos os níveis territoriais (local, municipal, estadual, central), ilustrando mais uma vez a tese de que as instituições, mais que simples reprodução do Estado (aparelhos), são contraditórias e funcionam como campo de luta (Luz, 1979). Neste sentido, creio que se deve considerar um segmento de profissionais e burocratas da área de saúde como vanguarda da descentralização e da desconcentração do poder estatal no inte- rior das políticas públicas brasileiras, sobretudo nos últimos quinze anos. Sua estratégia tem servido de modelo para outras áreas sociais, como a educação. Evidentemente, falo aqui de setores e não da totalidade dos profissionais e burocratas da saúde. Falo de atores políticos, e não de indivíduos.

Em seguida, cabe considerar o efetivo avanço de movimentos populares e de organizações da sociedade civil, desde a segunda metade da década de 1980 (Mattos, 1990), no sentido de reivindicar participação no planejamento e na gestão ("controle social”) dos serviços de saúde. Esse avanço tem caminhado da periferia para o centro, em termos territoriais e políticos, isto é, do local para o central. Os municípios e localidades são o grande eixo de mobilização pela descentralização em direção às Secretarias Estaduais de Saúde e ao poder central, no Ministério da Saúde. Além das organizações e associações locais comunitárias, atuantes desde o início dos anos 80, cabe assinalar, na década de 1990, o surgimento e desenvolvimento participativo das organizações não-governamentais (ONGs) e dos agentes comunitários de saúde, ambos com impacto na movimentação política civil envolvendo a questão da saúde.

A participação efetiva da sociedade civil nas políticas de saúde, resultante do entrosamento entre organizações civis e setores institucionais (profissionais, burocratas, gestores) tem variado de acordo com a cultura político partidária dominante nos governos de nível municipal (Pinheiro, 1996) ou - às vezes - estadual, e tem sido um elemento concreto de desconcentração do poder estatal atuando "de baixo para cima", embora ainda limitado a poucos estados e municípios. Poder-se-ia dizer que este entrosamento produtivo de participação constitui-se em um fator de democratização da política de saúde.

Por outro lado, as Conferências de Saúde, até o início dos anos 80 apenas em nível nacional, depois estadual, chegaram nos anos 90 a uma movimentação em nível municipal (base da pirâmide institucional, por assim dizer), com grande participação de delegados das esferas institucionais, ou eleitos nas comunidades locais, representando organizações civis (muitas vezes partidárias, ou religiosas). Seu acontecimento e organização demonstram o interesse popular na descentralização da política de saúde. Essa movimentação tem também o efeito de pressionar o Estado "de baixo para cima” no sentido da desconcentração, através da luta pela participação na gestão dos serviços. 
Evidentemente essa pressão pode encontrar reação mais ou menos positiva, com maior ou menor intensidade da parte do poder público. No que concerne ao governo central esta reação tem sido praticamente nula, em função da natureza das políticas vigentes no Estado neoliberal, que não ultrapassam o nível de "assistência" e de "proteção aos mais necessitados", geralmente em caráter emergencial.

Desta forma, do ponto de vista do seu conteúdo político, a política de saúde embutida na proposta original do Sistema Único de Saúde (SUS) nada tem a ver com as políticas neoliberais. Embora não se possa falar aqui de duas forças atuando em sentido contrário, pois vimos que ao Estado neoliberal também interessa a "descentralização", estamos em presença de pelo menos dois conteúdos políticos de sentidos opostos para a questão da descentralização/desconcentração na última década, em função dos três atores em presença: grupos da sociedade civil, atores institucionais da área de saúde e Estado (definido aqui em sentido estrito de esferas de governo). Nesta cena política os atores institucionais funcionam como correias de transmissão, ora "levando para dentro" ora "trazendo para fora" do Estado ${ }^{33}$, conforme seus interesses corporativos ou seus compromissos com o aparato estatal ou a sociedade civil, decisões e normas com maior ou menor grau de centralização ou concentração nas políticas de saúde.

No que concerne ao Estado visto como conjunto de esferas de governo, é preciso assinalar sua grande diversificação interna em direção ao âmbito local, operada na década de 1990, com a expansão dos municípios e o crescimento do peso dos governos municipais, através da expansão das prefeituras (e suas secretarias). Um dado significativo desse crescimento é a organização dos prefeitos em nível de associação nacional, bem como das câmaras legislativas, dando origem ao que se poderia denominar associativismo público, inédito no país. Evidentemente os municípios necessitam na atualidade se unir, como poder público, para fazer face ao poder central, no sentido de obter recursos orçamentários para suas atividades e evitar o colapso fiscal por endividamento. Quero acentuar aqui, que um novo ator político consolidou-se na década de 1990 em relação à questão da centralização versus descentralização das políticas públicas, e esse ator tende a ganhar importância na medida que cresce seu peso na balança política através das eleições. Neste sen- tido, afirmo que também o poder municipal tende a ser nos próximos anos uma esfera de governo que pressiona o Estado central "de baixo para cima” no sentido da descentralização/desconcentração das políticas públicas em geral, e em especial das políticas de saúde, em função do dispositivo descentralizador que representa o Sistema Único de Saúde (SUS).

Considerando-se apenas os atores recémanalisados poder-se-ia dizer que o movimento de descentralização e de desconcentração é, na política de saúde, uma tendência irreversível. Entretanto, têm que ser levadas em consideração as forças políticas que atuam em sentido contrário a essa tendência. Além da própria estrutura do Estado na conjuntura atual e das políticas que dela decorrem, existem os interesses de privatização, organizados desde os anos 70 (Luz, 1979), transformados em lobbies, nos anos 80 (Luz, 1991), e em poderoso ator político nos anos 90 (Luz, 1994): grandes laboratórios farmacêuticos, corporações médico hospitalares e serviços privados de saúde transformados em atividade financeira, ou em geral cartelizados. Essas forças sociais têm profunda presença em todos os níveis e esferas governamentais e pressionam fortemente o Estado no sentido de seus interesses. O Estado, por sua vez, tende a privatizar seus serviços e a limitar-se a ser apenas um regulador do mercado em relação a preços e qualidades de serviços e produtos oferecidos à população, na área de atenção médica. Desta forma, essas forças socialmente dominantes se complementam e tensionam as forças que atuam no sentido da descentralização e desconcentração das políticas de saúde.

Deve-se reassinalar, entretanto, o forte interesse do Estado central em transferir funções e serviços para sua periferia, em termos territoriais e de esferas de governo (serviços de saúde em nível local), o que efetivamente tem tido efeitos descentralizadores em relação à política de saúde. Foram criadas regulamentações assegurando essa efetiva transferência, inclusive em plano financeiro, dentre as quais as Normas Operacionais Básicas (NOB), editadas durante a década de 1990, são o instrumento normativo mais significativo. A regulamentação de conselhos de integração de gestão institucional, em níveis municipal e estadual, iniciada nos anos 80 sem grande adesão, também desenvolveu-se neste período, superando aos poucos o tradicional isolamento institucional no plano da gestão e do desenvolvimento de programas. Deste modo, pode-se dizer que na década de 
1990 houve descentralização na política de saúde brasileira, se entendida como delegação de funções ou transferência de ações (e sua gestão) para níveis territoriais menores e periféricos do sistema (municípios, localidades). Mas se considerada a concentração dos recursos na esfera central de governo, o férreo controle contábil exercido sobre os níveis periféricos, e a priorização de determinados programas verticais, não necessariamente coerentes com os escolhidos como prioritários em nível municipal, pode-se dizer que se trata até o momento de uma descentralização incompleta, que chega a inviabilizar, por insuficiência de recursos, parcial ou integralmente, o funcionamento de programas e serviços locais, sobrecarregando de maneira sobre-humana os profissionais de saúde e responsabilizando-os, às vezes de maneira espalhafatosa, ${ }^{34}$ pelas falhas resultantes do estrangulamento do sistema de atenção à saúde.

Posso concluir a análise desse período afirmando que se houve efetivamente descentralização na política de saúde na década encerrada, não houve - e nem poderia haver, considerando a composição do Estado e sua política dominante - desconcentração. Mas a pressão por parte de setores da sociedade civil, e segmento de profissionais e da burocracia, bem como do poder público em nível municipal é constante e, ouso afirmar, tende a crescer com o papel do poder local na política global nos anos vindouros, pressionando o Estado, na busca de democratização, o Estado no sentido da descentralização com desconcentração.

\section{Breve comentário sobre a produção do tema no campo da saúde coletiva}

O espaço que resta para o comentário a seguir é mínimo, considerada a importância e a proposta inicial do trabalho. Entretanto, visto o alongamento da análise das políticas de saúde em função do tema central, e o limite de páginas permitido para o artigo, vejo-me forçada a referir-me muito brevemente à produção do campo sobre o tema.

Em primeiro lugar devo assinalar que a área temática de produção a que me refiro restringe-se às políticas de saúde, que em si mesmo é muito recente e peculiar. Embora seja uma produção que absorva elementos das ciências sociais em suas análises, toma-os geralmente do ponto de vista da saúde pública ou da medicina preventiva, criando um híbrido analíti- co/normativo que, embora rico e interessante, tende a ser considerado conceitualmente "menor", ou mesmo invalidado pelas disciplinas duras das ciências humanas ou da medicina. Em segundo lugar, não tenho a pretensão de ser uma analista da produção de idéias neste campo, onde vários outros autores já desenvolveram trabalhos (Nunes, 1983, 1985, 2000; Birman, 1991; Canesqui, 1994). O que me interessa interrogar aqui são as tendências e lacunas teóricas referentes ao tema central destas páginas.

Quero destacar inicialmente que a produção de teses, livros, coletâneas e artigos sobre políticas de saúde não se desenvolveu antes dos anos 80. Mesmo considerando trabalhos pioneiros (Donnangelo, 1976; Guimarães, 1978; Luz, 1979), a reflexão sobre as políticas públicas era ainda muito escassa não apenas no campo da saúde mas no conjunto das ciências sociais, salvo exceções (Santos, 1979; Maloy, 1974). Preocupavam-se geralmente com a política econômica e o papel do Estado no desenvolvimento do país; e com as forças sociais capazes de produzir transformações no modelo econômico e na política, através de sua organização, mobilização ou resistência: empresários, sobretudo industriais, operários e camponeses. A análise do "milagre brasileiro" e seus efeitos sociais, através de uma abordagem econômica macro estrutural, de acentuada influência marxista, como observei no início deste trabalho, era dominante, e se constituía num esforço sério e consistente de reflexão sobre o processo de desenvolvimento capitalista brasileiro e o papel do Estado nesse processo.

Entretanto, acho interessante sublinhar o papel hegemônico dessa produção no campo da saúde coletiva durante a década de 1970 e a primeira metade dos anos 80 , e suas conseqüências em termos de estruturação do campo. Os estudos sobre a profissão médica (Donnangelo, 1975), sobre a organização do "setor saúde" ou da indústria farmacêutica (Cordeiro, 1980, 1984) e sobre a previdência social (Faleiros, 1980; Oliveira e Teixeira, 1985, entre outros), sendo este os principais temas de análise referidos às políticas de saúde, privilegiaram sistematicamente o desenvolvimento da economia capitalista em sua relação com o Estado (e vice-versa), como elementos de explicação teórica. Partindo de um esquema de interpretação macroestrutural econômico, esses estudos, em que pese a seriedade - e muitas vezes o brilhantismo - de suas análises, tendiam a transportar, às vezes com um dedutivismo mecânico, os es- 
quemas da economia, em sua vertente teórica marxista, para um campo muito complexo, de entroncamento de várias disciplinas, como o da saúde. Isso limitava - e a meu ver limita ainda hoje, quando esses esquemas são aplicados sem mediações - à compreensão de outros elementos importantes do ponto de vista político, que não eram tomados em consideração na análise. Entre esses elementos quero salientar as instituições de saúde, os movimentos sociais esses últimos, desde a segunda metade dos anos setenta, demonstraram nas ruas e nas organizações comunitárias e sindicais, seu papel de denúncia das políticas econômica e social do Estado - e os profissionais de saúde, sobretudo a burocracia, atores fundamentais para se entender o caminho das políticas de saúde no Brasil, em seu passado e em seu futuro (Luz, 1979, 1982, 1991). Em outras palavras, desejo assinalar que, desconsiderando durante quase uma década esses atores como elementos centrais de análise, o campo perdeu a oportunidade histórica e teórica de acompanhar, desde a década de 1970, o movimento das ciências socais em andamento na Europa (Espanha, Itália, França, Alemanha) e se iniciando na América Latina. Nesses contextos já eram tematizados os movimentos sociais, as transformações no Estado monopolista (sintomas do percurso que conduziria à globalização), bem como o surgimento de novos atores na política, como as instituições e - mais tarde - os próprios serviços de saúde. Tendo privilegiado a abordagem economicista, a produção acadêmica brasileira não teve, frente ao objeto políticas de saúde, uma capacidade analítica forte no plano político, reduzindo-o a mero reflexo do avanço da estrutura de produção capitalista, silenciando sobre estudos que já tematizavam essas questões. Seguindo mecanicamente o mainstream analítico das ciências sociais, tendeu a empobrecerse teoricamente face a seus objetos específicos.

A análise das instituições, por exemplo, que na década de 1990 começou a ser "descoberta" pelo campo, através do neoinstitucionalismo, entrou na área da saúde no fim dos anos 70 através da psiquiatria social, e do movimento antiinstitucionalista, liderado por autores como Robert Castel, Franco Basaglia e Michel Foucault. $\mathrm{Na}$ área sociológica, a escola institucionalista francesa chefiada por René Lourau teve também um grande impacto na década, na Europa. O rebatimento dessa produção no campo, em autores brasileiros foi considerável (Silva, 1976; Machado, 1978; Birman, 1978;
Costa, 1979; Luz, 1979; Albuquerque, 1980) ainda nos anos 70, sem considerar as traduções dos autores citados acima, abundantes no fim dos anos 70 e início dos 80. Entretanto, essa reflexão foi marginalizada na produção sobre as políticas de saúde. Do meu ponto de vista, por motivos ideológicos, o tema instituições era considerado exótico no campo da saúde pública, encontrando acolhimento apenas na área denominada $p s i$ (psicanálise, psiquiatria, psicologia).

Minha hipótese para interpretar a atribuição de exotismo ao tema das instituições considera que o conceito de poder institucional, crucial nessas análises, ao não implicar necessariamente a questão do capital e da estrutura de dominação de classes, ou do avanço da produção capitalista, não encontra lugar teórico no esquema marxista clássico. ${ }^{35} \mathrm{Na}$ verdade, a questão conceitual das instituições era vista, nesse esquema, como secundária; e a dominação política, como dimensão do cotidiano das vidas dos trabalhadores, dos pacientes, e mesmo dos profissionais, fugia ao âmbito objetivo da esfera macro estrutural. Sendo assim Não eram consideradas temas importantes nem do ponto de vista teórico nem do ponta de vista político para o campo da saúde pública, (excetuando-se a área de psiquiatria social) na segunda metade da década de 1970 e primeira metade dos anos 80 .

Da mesma forma, o tema dos movimentos sociais, que teve impulso na Europa já nos anos 70 e se aprofundou no início dos anos 80 (movimento de mulheres, de moradores, de pacientes, dentre outras) somente é considerado importante no campo das ciências sociais, e sobretudo no da saúde coletiva no Brasil, a partir da segunda metade dos anos 80 . Também esse tema, que foge à primeira vista ao nível macro estrutural, não encontra guarida nas análises marxistas hegemônicas no campo, centradas no Estado e na economia capitalistas.

Nessas análises, o Estado era visto ora como entidade monolítica todo poderosa, ora como marionete das forças do capital e das forças sociais que o compõem. A pluralidade de atores, muitas vezes agindo contraditoriamente em seu interior (profissionais de atividades "fim", burocracia), as resistências oferecidas pelos movimentos da sociedade civil, as novas forças ali emergentes como atores em relação à saúde, como mulheres, pacientes, estudantes (residentes, por exemplo) raramente encontravam espaço nessas análises. E no entanto elas já 
eram atuantes. De meu ponto de vista isto significa que o campo era pouco sensível aos seus possíveis objetos, devido a um parti pris teórico/político inicial. Creio que o fantasma deste parti pris só veio a ser realmente exorcizado no campo nos anos 90, com a presença de novos esquemas analíticos, mais complexos e integradores de disciplinas das ciências humanas até então pouco significativas, como a história, a antropologia e a psicanálise. Entretanto, somente a análise dessa produção poderia confirmar esta crença.

\section{Notas}

1 Além dos três trabalhos mencionados acima, outros focalizam a questão das políticas de saúde, mais centrados nas relações entre movimentos da sociedade civil e instituições de saúde ou na ordem burocrática institucional e os cidadãos. Serão mencionados no decorrer deste artigo.

2 Entre essas dissertações e teses já defendidas sobressaem-se as de Pinheiro, R. "Conselhos Municipais de Saúde: o avesso e o direito”, dissertação de mestrado em saúde coletiva, Instituto de Medicina Social/UERJ, 1995; Pinheiro, R. "Da defesa do aço à defesa da vida: o Sistema Único de Saúde em volta Redonda", tese de doutorado em saúde coletiva, Instituto de Medicina Social/UERJ, 2000; Pinheiro, MCC. "Da segurança alimentar à vigilância da fome: delineando a história de um hiato", dissertação de mestrado em saúde coletiva, IMS/UERJ, 1996; Nogueira, RP. "A saúde pelo avesso - revisitando Illich, o profeta da autonomia", tese de doutorado em saúde coletiva, IMS/UERJ, 1998; Carmo, DS. "Cidadania hoje: a atualidade da contribuição de Rousseau”, dissertação de mestrado em saúde coletiva, IMS/UERJ, 1999; Dalcanale, CT. "Crise da atenção à saúde e a biomedicina - reflexões críticas e propostas”, dissertação de mestrado em saúde coletiva, Departamento de Medicina Preventiva/UNICAMP, em co-orientação com Gastão Wagner dos Santos. Além dessas, outras em andamento tematizando alguns aspectos da questão das instituições e políticas de atenção à saúde, bem como as estratégias e práticas relativas à saúde desenvolvidas na sociedade civil, levam-me a manter constante reflexão sobre esta área.

3 A discussão sobre essa dicotomia na Primeira República, no momento da implantação do modelo sanitarista campanhista de Oswaldo Cruz como eixo central da política de saúde do jovem estado republicano brasileiro, está no livro Medicina e ordem política brasileira (1982).

${ }^{4}$ A questão do campanhismo como política de saúde pública foi discutida pela primeira vez no livro As instituições médicas no Brasil (1979), e em seguida no livro Medicina e ordem politica brasileira (1982), sendo retomada no artigo "Notas sobre as políticas de saúde no Brasil de transição democrática - anos 80 ", numa perspectiva analítica das recorrências históricas nas políticas de saúde.

5 Discuti o tema da descentralização/desconcentração nos trabalhos Medicina e ordem politica brasileira e "Notas sobre as políticas de saúde no Brasil de transição democrática - anos 80". Também no capítulo: As Conferên- cias Nacionais de Saúde - as políticas de saúde nos anos 80, em Guimarães R. e Tavares R. Saúde e sociedade nos anos 80 (Rio de Janeiro, Ed. Relume Dumará/Abrasco/ Ims-UERJ), pp.131-154, ressaltando a relação e a distinção que pode ser feita entre os dois termos.

6 Uma analogia pode ser feita entre este tipo de poder de estado e o Estado absolutista europeu que precedeu a república moderna. A vontade política transmitida às instituições, neste caso, é uma vontade política de natureza imperial. Mais adiante discutirei esta questão.

7 Ver a este propósito a discussão clássica de Marshall sobre cidadania e desenvolvimento social.

8 O que não significa que esses movimentos ou partidos não existissem. Os movimentos republicanos e as revoltas populares republicanas existem desde as primeiras décadas do século XIX, e pipocam aqui e acolá pelo Brasil desde a Independência. Ver a este propósito Luz, M T. Medicina e ordem politica brasileira (op. cit.), Luz, MT. A arte de curar versus a ciência das doenças - história social da homeopatia no Brasil (São Paulo, Dynamis Editorial, 1996) e Carvalho, JM. A formação das almas. O imaginário da República no Brasil (Rio de Janeiro, Companhia das Letras, 1990).

${ }^{9}$ Essas análises embasaram algumas das afirmações dos livros As instituições médicas no Brasil e, sobretudo, Medicina e ordem política brasileira, ambos já mencionados.

10 Venho tentando demonstrar esta tese nos livros As instituições médicas no Brasil e Medicina e ordem política brasileira; também nos artigos "Notas sobre as políticas de saúde no Brasil de transição democrática - anos 80", "Burocracia, aparato estatal y sociedad civil a partir de políticas sociales en la sociedad brasileña, elementos para un análisis comparativo", entre outros trabalhos. Entretanto, somente nos anos 90 os estudos do campo da saúde coletiva se debruçaram seriamente sobre as instituições de saúde e a sociedade civil, descentrando o olhar analítico da imagem toda poderosa do Estado. Comentarei mais adiante a questão da produção deste tema no campo da saúde coletiva.

11 Evidente que esta proposição "ideal” jamais se cumpre integralmente na prática. Poder-se-ia dizer que, de certa maneira, a maior parte da luta política dos últimos dois séculos tem sido no sentido de "fazer cumprir" o ideário 
republicano democrático, mesmo no caso das lutas pelo socialismo. O que se pode por em questão são os limites de tal cumprimento em uma sociedade marcada por desigualdades de classe como o capitalismo. Sobretudo em sociedades com desigualdade social profunda, como o Brasil. Em última instância esse é o limite básico para a desconcentração nas políticas.

12 Outra questão pouco tratada durante anos nas análises sobre políticas de saúde é esta face de resistência às políticas estatais, encarnada nos movimentos sociais e nos profissionais das instituições de saúde.

13 Ainda no final do século XX, durante a década de 1990, o Brasil disputava os primeiros lugares em concentração de renda e desigualdade social do planeta.

14 Sanitarismo campanhista foi a expressão cunhada no livro As instituições médicas no Brasil e retomada no livro Medicina e ordem política brasileira, para designar um modelo específico de intervenção institucional médica com vistas ao controle de epidemias e endemias na sociedade brasileira. Não chega a ser um conceito, mas é uma categoria de análise.

15 Há uma "pauta” social considerável de reivindicações envolvendo a questão da saúde na República Velha. Trabalhadores, membros de organizações civis e grupos intelectuais se mobilizam intensamente no período de Oswaldo Cruz no sentido da defesa dessa pauta, indo até a episódios de resistência armada à política sanitária.

16 Este período é marcado por exposições e "feiras" internacionais de ciência, tecnologias e invenções, como a da grande exposição mundial de Paris de 1900. No Brasil também tem lugar esses eventos.

17 É necessário acentuar, uma vez mais, que isto não significa que já não existissem movimentos organizados de trabalhadores em prol da saúde, reivindicando direitos e medidas específicas das autoridades sanitárias. Apenas essas reivindicações não eram tomadas em consideração pelo poder público (como ademais raramente o são até nossos dias).

18 Os modelos de política de saúde na Primeira e na Segunda Repúblicas são discutidos comparativamente nos trabalhos As instituições médicas no Brasil (op. cit.) e "Notas sobre as políticas de saúde no Brasil de transição democrática - anos 80 " (op. cit.), salientando-se a questão das dicotomias centralização/descentralização e concentração/desconcentração do poder estatal na sociedade brasileira.

19 Esta discussão da burocratização de serviços e campanhas sem descentralização foi feita por esta autora desde o trabalho As instituições médicas no Brasil, e retomada no trabalhos Medicina e ordem política brasileira e "Notas sobre as políticas de saúde no Brasil de transição democrática - anos 80 ".

20 No próprio texto do terceiro capítulo do livro As instituições médicas no Brasil esta classificação aparece, assumindo a perspectiva de Weffort e seus artigos dos anos 70 sobre a questão sindical e o Estado. Em que pese o inegável clientelismo então vigente nas relações gover- no/sindicatos e estado/funcionalismo, assim como a simbiose nas relações entre governo e partido oficial (PTB), a diversidade sindical, com suas lutas internas, a oposição parlamentar poderosa e não menos clientelista que a da situação, a existência de uma opinião pública ativa manifesta na crescente liberdade de imprensa e de associação apontam, nos quinze anos que vão de 1950 a 1964 (incluindo o período juscelinista de 56 a 60), para um período excepcional de vigorosa e inédita vida democrática entre nós, ainda que as várias ameaças e tentativas de golpe militar colocassem o país em estado de contínua tensão política.

21 A oposição lacerdista expressa no jornal Tribuna da Imprensa, veículo das opiniões do partido União Democrática Nacional (UDN), emprega com freqüência essa expressão, manifestando o receio de que o Brasil venha a se tornar uma sociedade socialista do tipo sindical, ou que se torne uma segunda Cuba no continente. É necessário lembrar que a revolução cubana é vitoriosa em 1959, colocando em alerta máximo a vigília americana sobre a América Latina na conjuntura da guerra fria.

22 É preciso levarmos em consideração que a ordem política brasileira quase nunca admitiu legalmente a existência de agremiações ou associações de caráter contestatário à ordem política vigente, como partidos ou sindicatos comunistas, anarquistas etc., geralmente ligados a forças sociais subordinadas, como camponeses, operários, ou resultantes de suas alianças. Somente no inicio dos anos 80 pode ser admitida e mantida uma força de oposição como o PT (Partido dos Trabalhadores), constatada sua desvinculação de correntes "subversivas".

23 Não é apenas na conjuntura dos anos 50-60 que propostas de descentralização/desconcentração de serviços públicos aparecem. Na área de saúde pública, já nos anos 30, com Pedro Ernesto, surge a proposta de organização de serviços de saúde descentralizados e hierarquizados. Nos anos 80 essas propostas voltam impulsionadas por movimentos sociais pela saúde. Nos anos 90 se consolidam nas propostas do SUS.

$24 \mathrm{O}$ "pouco" a que aludo refere-se à experiências-piloto de programas locais e municipais de saúde, como o PIASS, baseadas em atenção primária, desenvolvidas nos anos 70 sob inspiração e comando de órgãos internacionais como a Organização Pan-Americana da Saúde (OPAS).

25 Tem início, nesse momento, uma fase de mobilização e organização popular em torno da questão da saúde que não parou de crescer na década de 1990 e que tem servido como uma das alavancas principais à política municipalizante do SUS.

26 Deve ser assinalado que o Brasil tornou-se, na última década, uma das dez primeiras economias do planeta em volume e dinamismo (às vezes a oitava, outras a nona), o que nos situa muito longe de economias esgotadas ou em escombros, como as da Rússia e leste europeu, ou esquálidas como as da África.

27 Dados do IBGE e de outras instituições que acompanham o desenvolvimento da economia e da estrutura da renda e do emprego no Brasil, como a FIPE e o DIEESE, são unânimes em constatar, paralelamente ao crescimen- 
to do desemprego e do recuo de certas atividades vitais na economia sobretudo na indústria, o agravamento da concentração de renda nos anos 90. Esses dados têm sido amplamente divulgados na imprensa nos meses iniciais do ano 2000, através dos diversos "balanços da década".

28 Este empobrecimento e seu ritmo tem sido o tema dominante de discussões de organismos internacionais, de livros e artigos de cientistas sociais e economistas, de organizações não-governamentais, da grande imprensa diária e hebdomadária, não importando sua tendência de opinião. Tornou-se um impasse para o avanço do capitalismo a longo prazo, definindo-se aqui a expressão "longo prazo" como poucas décadas.

29 No momento de elaboração final deste artigo, nos meses de janeiro e fevereiro de 2000, várias reportagens sobre o aumento do desemprego na década de 1990 e a piora das perdas salariais, medidas pelo IBGE, foram publicadas em diários como o Jornal do Brasil e a Folha de S. Paulo. A discussão sobre a concentração de renda, o encolhimento do salário mínimo e sua insuficiência atinge fóruns internacionais e parece preocupar agora o próprio presidente da República (ver, por exemplo, Jornal do Brasil, $1^{\circ}$ de março de 2000, p. 5).

30 Outro sentido do termo neoliberal refere-se às políticas públicas da fase pós-fordista no capitalismo internacional, com o advento das políticas sociais "tatcherianas".

31 Ver a este propósito a matéria "Déficit atinge 55,53\% das prefeituras", da Folha de S. Paulo, de 31 de janeiro de 2000, onde o jornalista Plínio Fraga mostra, com base em levantamento feito pelo IBAM, e dados do Banco Central, o endividamento de mais de $50 \%$ das prefeituras brasileiras, acentuando o papel da descentralização e da "financeirização" do repasse de verbas aos municípios nesse processo.

32 “Oração da Paz”, atribuída a São Francisco de Assis.

33 Quero alargar, com a idéia de "correia de transmissão" para os atores institucionais, um pouco mais a concepção já clássica dos "anéis burocráticos", criando a imagem de um dinamismo de ida e volta transformador, isto é, que

\section{Referências bibliográficas}

Albuquerque JAG 1980. Instituição e poder. Graal, Rio de Janeiro. 163 pp.

Albuquerque MM 1981. Pequena história da formação social brasileira. Graal, Rio de Janeiro.

Birman J 1978. A psiquiatria como discurso da moralidade. Graal, Rio de Janeiro.

Birman J 1991. A physis da Saúde Coletiva. Physis, 1(1):711.

Canesqui A 1994. Notas sobre a produção acadêmica de antropologia e saúde na década de 80. In Alves PC e Minayo MC (orgs.). Saúde e doença: um olhar antropológico. Editora Fiocruz, Rio de Janeiro.

Carmo DS 1999. Cidadania hoje: a atualidade do pensamento de Rousseau. Dissertação de mestrado. Instituto de Medicina Social/UERJ, Rio de Janeiro. não apenas "traz" do Estado para a sociedade civil suas perspectivas e decisões, mas também "leva de volta” da sociedade civil para o Estado as opiniões de grupos mais ou menos organizados, aos quais os agentes institucionais geralmente pertencem.

34 Desde o início dos anos noventa, com o governo Collor, os responsáveis pela política de saúde no país tornaram-se homens da mídia, comparecendo sob a luz de refletores de televisões a serviços hospitalares, maternidades, berçários etc. para "dar flagrantes" de mau atendimento em unidades totalmente abandonadas de recursos pelo poder público, onde os profissionais desempenham suas funções como numa frente de batalha. Inútil mencionar a manipulação da opinião pública no sentido de isentar os governos de suas responsabilidades, transformando os profissionais em bodes expiatórios da política de saúde. Não pode, por este motivo, deixar de ser mencionado que nos anos 90 o Estado tratou sua força de trabalho na área de saúde - ou recursos humanos em saúde, para empregar o jargão institucional - de forma predatória, pela defasagem crescente de seus salários, pela quase inexistência de recursos para atender ao crescimento da demanda por atenção médica, ou ao menos para repor o contingente de profissionais em função de mortes e aposentadorias, e pela exigência de uma crescente "produtividade" desacompanhada de condições mínimas de trabalho adequadas para o desempenho de suas funções. $\mathrm{O}$ reflexo dessa situação na saúde dos profissionais tem sido dramático, sobretudo entre os médicos, como atestam dados recentes sobre morbidade.

35 Refiro-me ao marxismo que considera a relação de determinação esquemática entre forças produtivas e relações de produção, e define o Estado como superestrutura da estrutura econômica, sem autonomia em relação à mesma. Outras versões marxistas são possíveis, entre as quais a althusseriana (em moda nos anos 70 no Brasil) e a gramsciana, que consideram a autonomia relativa das esferas do político e do ideológico face à economia, e que definem o Estado de modo bastante complexo. Antônio Gramsci é um fino analista da cultura e das instituições. Uma parte de minhas opções conceituais na área de políticas de saúde (Luz, 1979, 1982, 1991, 1992, 1994) são tributárias deste autor

Carone E 1977. Revoluções do Brasil contemporâneo: 1922-1937. DIFEL. São Paulo.

Carvalho JM 1990. A formação das almas. O imaginário da República no Brasil. Companhia das Letras, Rio de Janeiro.

Castel R 1995. Les metamorphoses de la question sociale. Une chronique du salariat. Ed. Fayard, Paris.

Cordeiro H 1980. A indústria da Saúde no Brasil. GraalCEBES, Rio de Janeiro.

Cordeiro H 1984. As empresas médicas. Graal, Rio de Janeiro.

Costa JF 1979. Ordem médica e norma familiar. Graal, Rio de Janeiro.

Costa NR 1985. Lutas urbanas e controle social. Ed. Vozes, Petrópolis. 
Dalcanale CT 1999. Crise da atenção à saúde e a biomedicina. Dissertação de mestrado. Departamento de Medicina Preventiva/UNICAMP. Campinas.

Donnangelo MCF e Pereira L 1976. Saúde e sociedade. Duas Cidades, São Paulo.

Donnangelo MCF 1975. Medicina e sociedade: o médico e seu mercado de trabalho. Livraria Pioneira Ed., São Paulo.

Faleiros VP 1980. A política social do estado capitalista. Cortez Ed., São Paulo.

Faoro R 1958. Os donos do poder. Ed. Globo, Porto Alegre.

Fernandes F 1975. A revolução burguesa no Brasil. Zahar Editores, Rio de Janeiro.

Guimarães R (org.). 1978. Saúde e medicina no Brasil: contribuição para um debate. Graal, Rio de Janeiro.

Ianni O 1971. Estado e planejamento no Brasil. Ed. Civilização Brasileira, Rio de Janeiro.

Ianni O 1971. O colapso do populismo no Brasil. Civilização Brasileira, Rio de Janeiro.

Ianni O 1973. Populismo e classes subalternas. Debate e Crítica (1), jul./dez.

Ianni O 1974. O estado e a acumulação capitalista. Debate e Crítica (3), julho.

Ianni O 1975. A formação do estado populista na América Latina. Civilização Brasileira, Rio de Janeiro.

Kowarick L 1971. Estratégias de planejamento social no Brasil. Cadernos CEBRAP, no.2.

Kurz R 1997. Os últimos combates. Ed. Vozes, Petrópolis.

Luz MT 1979. As instituições médicas no Brasil - instituição e estratégia de hegemonia. Graal, Rio de Janeiro, 295 pp.

Luz MT 1982. Medicina e ordem política brasileira. Graal, Rio de Janeiro, $218 \mathrm{pp}$.

Luz MT 1991. Notas sobre as políticas de saúde no Brasil de transição democrática - anos 80. Physis 1(1):77-96.

Luz MT 1992. Burocracia, aparato estatal y sociedad civil a partir de políticas sociales en la sociedad brasileña: elementos para un análisis comparativo, pp. 277-292. In Fleury SMT. Estado y políticas sociales en América Latina. Universidad Autonoma Metropolitana. Fiocruz-ENSP, Xochimilco-Rio de Janeiro.

Luz MT 1994. As Conferências Nacionais de Saúde e as Políticas de Saúde da Década de 80,pp. 131-152. In Guimarães R e Tavares R (orgs.). Saúde e sociedade no Brasil, anos 80. Abrasco/Ims-Uerj/Relume Dumará, Rio de Janeiro.

Machado R et al. 1978. Danação da norma - medicina social e constituição da psiquiatria no Brasil. Graal, Rio de Janeiro.

Malloy J 1976. Previdência social e classe operária no Brasil (uma nota de pesquisa). Estudos CEBRAP, n. 13 .

Marshall TH 1964. Class, citizenship and social development. Doubleday, Londres.

Martins L 1975. Nação e corporação multinacional. Editora Paz e Terra, Rio de Janeiro.

Mattos MAS 1990. Participação popular ou cidadania regulada. Movimentos populares pela saúde no Rio de Janeiro (1980-1988). Instituto de Filosofia e Ciências
Sociais/Universidade Federal do Rio de Janeiro, Rio de Janeiro.

Moura C 1978. A sociologia posta em questão. Livraria Ed. Ciências Humanas, São Paulo.

Nogueira RP 1998. A saúde pelo avesso: revisitando Illich, o profeta da autonomia. Tese de doutorado. Instituto de Medicina Social, Universidade do Estado do Rio de Janeiro, Rio de Janeiro.

Nunes ED (org.). 1983. Medicina social - aspectos históricos e teóricos. Global Editora, São Paulo.

Nunes ED 1985. As ciências sociais nos planos de estudo de graduação e pós-graduação, pp. 427-455. In As ciências sociais em saúde na América Latina: tendências e perspectivas. OPAS, Brasília,

Nunes ED 2000. Ensinando ciências sociais em uma escola de medicina: a história de um curso (1965-90). História, Ciências Saúde, vol. VI(3):631-657.

Oliveira F 1972. Crítica à razão dualista. Estudos CEBRAP, n. 2, São Paulo.

Oliveira JA e Teixeira SMF 1985. Previdência Social - 60 anos de história da previdência no Brasil. Editora Vozes, Petrópolis.

Pinheiro MCC 1996. Da segurança alimentar à vigilância da fome: delineando a história de um hiato. Dissertação de mestrado. Instituto de Medicina Social, Universidade do Estado do Rio de Janeiro.

Pinheiro PS 1975. Política e trabalho no Brasil. Paz e Terra, Rio de Janeiro.

Pinheiro R 1995. Conselhos Municipais de Saúde: o avesso e o direito. Dissertação de mestrado. Instituto de Medicina Social, Universidade do Estado do Rio de Janeiro, Rio de Janeiro.

Pinheiro R 2000. Da defesa do aço à defesa da vida. O cotidiano dos atores em suas práticas nos serviços de saúde: o caso de Volta Redonda. Tese de doutorado. Instituto de Medicina social, Universidade do Estado do Rio de Janeiro, Rio de Janeiro.

Santos WG 1979. Cidadania e justiça. Ed. Campus, Rio de Janeiro.

Silva MGR 1976. Prática médica: dominação e submissão. Zahar, Rio de Janeiro.

Singer P 1976. A crise do milagre. Editora Paz e Terra, Rio de Janeiro.

Soares LTR 1999. Ajuste neoliberal e desajuste social na América Latina. Editora da UFRJ, Rio de Janeiro.

Tavares MC e Fiori JL 1997. Poder e dinheiro. Uma economia política da globalização. Ed. Vozes, Petrópolis.

Vianna MLW 1976. Liberalismo e sindicato no Brasil. Editora Paz e Terra, Rio de Janeiro.

Vianna MLW 1998. A americanização (perversa) da seguridade social no Brasil. Estratégias de bem-estare políticas públicas. Ed. Revan-IUPERJ/UCAM, Rio de Janeiro.

Weffort FC 1973. Origens do sindicalismo populista no Brasil (A Conjuntura do após-guerra). Estudos CE$B R A P$, n. 4.

Weffort FC 1978. Os sindicatos na política (Brasil 19551964). Ensaios de Opinião (7). 